Матеріали Всеукраїнської науково-практичної конференції «Актуальні питання діагностики, лікування, раціональної фармакотерапії, диспансеризації та реабілітації в практичі сімейного лікаря"

DOI

\title{
ВПЛИВ КОМПЕНСАЦІЇ ЗАХВОРЮВАННЯ НА ВМІСТ РЕЗИСТИНУ У ХВОРИХ НА ЦУКРОВИЙ ДІАБЕТ 2 ТИПУ
}

๑А. М. Урбанович

\section{Львівський національний медичний університет імені Данила Галицького}

Актуальність. Дослідження, які ведуться із вісімдесятих років минулого століття, мають на меті з'ясування ролі гормонів жирової тканини у патогенезі ЦД 2 типу та його ускладнень. Доведено, що низка біологічно активних сполук жирової тканини, зокрема резистин, мають прозапальний потенціал, проте мало відомо про його взаємозв'язок із ступенем компенсації ЦД 2 типу.

Мета дослідження - вивчити можливий взаємозв'язок між вмістом резистину сироватки крові у пацієнтів із ЦД 2 типу та станом компенсації діабету.

Матеріали та методи. Обстежено 305 пацієнтів із ЦД 2 типу (154 жінки та 151 чоловік), які були поділені на три групи: 1 група - із доброю компенсацією ЦД (НbA1c $\leq 7$ \%), 2 група - із задовільною компенсацією (НbA1с 7,1-8 \%), 3 група із незадовільною компенсацією (НbA1c $\geq 8,1 \%$ ). Діагноз та компенсацію ЦД 2 типу верифікували згідно з наказом МОЗ № 1118 від 21.12.12.

Кров для аналізу забирали натщесерце. Piвень резистину в крові визначали імуноферментним методом («ELISA») за допомогою набору реактивів фірми «BioVendor» (Німеччина), рівень інсуліну в крові визначали імуноферментним методом («ELISA») за допомогою набору реактивів фірми «DRG» (Німеччина), рівень НbA1с визначали методом катіонообмінної хроматографії високого тиску за допомогою автоматичного аналізатора «BioradD-10». Загальна характеристика обстежених пацієнтів представлена у таблиці 1.

Таблиця 1. Загальна характеристика обстеженого контингенту

\begin{tabular}{|l|c|c|c|}
\hline \multicolumn{1}{|c|}{ Параметр } & Група 1 & Група 2 & Група 3 \\
\hline Кількість (Ж:Ч) & $52(29: 23)$ & $80(40: 40)$ & $53,56 \pm 0,47$ \\
\hline Вік, роки & $55,03 \pm 0,87$ & $52,76 \pm 1,30$ & $31,55 \pm 0,48$ \\
\hline IMТ, кг/м² & $32,15 \pm 4,89$ & $31,28 \pm 0,98$ & $10,82 \pm 0,15^{*} / * *$ \\
\hline НЬА1с, \% & $6,43 \pm 0,07$ & $7,55 \pm 0,04 *$ & $18,46 \pm 0,71$ \\
\hline Інсулін, мкОд/мл & $21,61 \pm 1,91$ & $23,33 \pm 2,32$ & \\
\hline
\end{tabular}

Примітки: * - вірогідно відрізяється від 1 групи; */**- вірогідно відрізняється від 1 та 2 груп.

Результати. Виявлено наступні відмінності у вмісті резистину: група $1-2,99 \pm 0,27$ нг/мл (Р1-

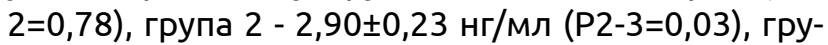
па $3-3,87 \pm 0,18$ нг/мл (P1-3=0,04). Вміст резистину достовірно був найвищий у групі пацієнтів із поганою компенсацією діабету.

$€$ дані, що рівень резистину впливає на рівень глюкози і вільних жирних кислот та знижує чутливість тканин до інсуліну. Поєднання цих факторів повинно спричиняти інсулінорезистентність (IP), але результати досліджень цього питання все ще залишаються суперечливими. Тривають пошуки механізму, який спричиняє розвиток IP під впливом гіперрезистинемії. Численні дослідження, проведені на мишах, вказують, що резистин відіграє певну роль в метаболізмі глюкози. Так, при проведенні дослідження на трансгенічних мишах із хронічною гіперрезистинемією виявлено, що резистин має функцію білка, який бере участь у регуляції гомеостазу глюкози і, відповідно, ії хронічно висока концентрація у крові веде до гіперглікемії натще та нетолерантності до глюкози. У нашому дослідженні ми теж бачимо зростання вмісту резистину при декомпенсації ЦД 2 типу.

M. Gnacinska доводить, що у експерименті при введенні у культури адипоцитів рекомбінованого резистину порушується стимульоване інсуліном поглинання глюкози, тоді як антитіла до резистину гальмують цей ефект. Окрім того, досліджуваний адипокін нейтралізує гальмівну дію інсуліну на продукцію глюкози печінкою і знижує поглинання її скелетними м'язами. Патогенетична роль резистину у механізмах розвитку IP недостатньо вивчена, адже не знайдено його рецептора. Встановлено, що при зниженні вмісту резистину сироватки крові покращується гомеостаз глюкози внаслідок гальмування процесів глюконеогенезу упечінці.

Висновки. При ЦД 2 типу формується новий рівень регуляторних взаємозв'язків, де важливе значення мають зміни у синтезі гормонів жирової тканини. Резистин, ймовірно, бере участь у регуляції стану компенсації ЦД 2 типу, що дає підстави розробляти комплексну терапію, спрямовану на пригнічення неспецифічного запалення та нормалізацію синтезу прозапальних адипокінів. 